\title{
ANALISIS KEJADIAN BRONCHITIS PADA MASYARAKAT PEMECAH BATU LALOWARU KONAWE SELATAN
}

\author{
Nirwana ${ }^{1}$, Erdiyanto ${ }^{2}$ \\ ${ }^{1}$ Balai Pelatihan Kesehatan Prov. Sultra, ${ }^{2}$ STIK Avicenna Kendari \\ Email : Odhyn.erdiyanto@yahoo.co.id
}

\begin{abstract}
Abstrak
Penelitian ini dilakukan untuk menganalisis faktor yang mempengaruhi kejadian bronchitis pada pekerja pemecah batu di Wilayah Kerja Puskesmas Moramo Utara Kabupaten Konawe Selatan. Jenis penelitian ini adalah Deskriptif Analitik dengan rancangan Case Control. Penelitian telah dilakukan selama 4 minggu, dari bulan Oktober sampai November 2015. Populasi penelitian adalah semua pekerja pemecah batu yang berada di wilayah kerja Puskesmas Lalowaru Kecamatan Moramo Utara Kabupaten Konawe Selatan tahun 2015 dengan jumlah sampel 58 responden, terbagi menjadi 28 responden sampel kasus dan 28 responden sampel kontrol. Pengambilan sampel dilakukan dengan metode stratified random sampling. Data diolah menggunakan program komputer. Hasil penelitian menunjukkan bahwa tidak ada pengaruh antara penggunaan alat pelindung diri $(O R=2,750)$ dan status gizi $(O R=3,178)$ terhadap kejadian bronchitis. Sedangkan lama paparan $(\mathrm{OR}=4,636)$ mempunyai pengaruh terhadap kejadian bronchitis pada masyarakat pemecah batu di wilayah kerja Puskesmas Lalowaru Kecamatan Moramo Utara Kabupaten Konawe Selatan tahun 2015. Saran dalam penelitian ini adalah melakukan pemeriksaan secara periodik dan teratur untuk memantau kondisi kesehatan fisik dan meningkatkan pengetahuan pekerja pemecah batu, dalam meningkatkan upaya perlindungan diri terhadap penyakit akibat kerja yang mungkin saja terjadi secara berulang-ulang.
\end{abstract}

Kata Kunci : bronchitis, pemecah batu, APD, status gizi.

\begin{abstract}
The purpose of research is to analyze factor influence occurrence of bronchitis the community breaking stones at Lalowaru Community Health Centre area North Moramo Sub districts South Konawe Regency. Characteristic of research is descriptive analysis using case control planning approach. Research has been heald off four weeks, from October until November 2015. Populations amount of research are all community breaking stones at Lalowaru Community Health Centre area North Moramo Sub districts South Konawe Regency in amount 56 samples, consist of 28 respondents in case group and 28 respondents in control group, take by using Stratified Random Sampling technique. Data of research are processed by using computer device IBM SPSS program version 20. Result of research showed the there are not influences of factors : using personal protective equipment with value of $(O R=2.750)$, and is nutritional status with value of $(O R=3.178)$ to occurrence of bronchitis of community breaking stones at Lalowaru Community Health Centre area North Moramo Sub districts South Konawe Regency 2015. Factors influence occurrence of bronchitis is long period of exposure with value of $(O R=4.636)$. Suggestions of this research is recommended perform periodic inspection and regular monitoring of physical health conditions and improve knowledge worker stone crushers, in increasing efforts to protect themselves against occupational diseases which may occur repeatedly.
\end{abstract}

Key Words : Bronchitis, breaking stones, personal protective equipment, nutritional status

\section{PENDAHULUAN}

Pada saat ini sedang berkembang pesat usaha dalam mencari berbagai faktor yang memegang peranan dalam timbulnya berbagai masalah penyakit tidak menular seperti kanker, penyakit sistemis, serta berbagai penyakit menahun lainnya termasuk masalah gangguan saluran pernafasan. Meningkatnya masalah kesehatan juga berhubungan erat dengan berbagai gangguan kesehatan akibat kemajuan dalam berbagai bidang terutama bidang industri yang banyak mempengaruhi keadaan lingkungan, 
termasuk lingkungan fisik, biologis, maupun lingkungan sosial budaya (Noor, 2009).

Gangguan saluran pernafasan akibat debu dapat dipengaruhi oleh karakteristik debu tersebut yang meliputi ukuran partikel, bentuk, konsentrasi, daya larut dan sifat kimiawi, serta lama paparan. Disamping itu, faktor individual seperti; mekanisme pertahanan paru, anatomi dan fisiologi saluran napas serta faktor imunologis. Penilaian paparan pada manusia perlu dipertimbangkan mengenai sumber paparan, jenis pabrik, lamanya paparan, paparan dari sumber lain. Selain itu, pola aktivitas seharihari dan faktor penyerta lainnya seperti umur, jenis kelamin, etnis, kebiasaan merokok dan faktor allergen (Lestari, 2000).

Faktor lingkungan juga dapat menjadi penyebab timbulnya penyakit akibat kerja. Potensi bahaya dapat ditimbulkan dari aktivitas di tempat kerja yang setiap saat dapat membahayakan pekerja. Berdasarkan uraian tersebut di atas, maka peneliti mengadakan penelitian mengenai analisis faktor yang mempengaruhi kejadian bronchitis pada masyarakat pemecah batu di Wilayah Kerja Puskesmas Lalowaru Kecamatan Moramo Utara Kabupaten Konawe Selatan.

\section{METODE PENELITIAN}

Penelitian dilakukan di wilayah kerja Puskesmas Lalowaru Kecamatan Moramo Utara, Kabupaten Konawe Selatan. Jenis penelitian adalah penelitian deskriptif analitik dengan pendekatan case control. Penelitian ini mempelajari faktor risiko dengan menggunakan pendekatan retrospektif, dimulai dengan mengidentifikasi kelompok yang terkena penyakit atau efek tertentu (kasus) dan kelompok tanpa efek (kontrol), kemudian mengidentifikasi faktor risiko terjadinya pada waktu yang lalu, sehingga dapat menerangkan mengapa kasus terkena efek, sedangkan kontrol tidak terkena efek.

Populasi penelitian adalah semua pekerja pemecah batu yang berada di wilayah kerja Puskesmas Lalowaru Kecamatan Moramo Utara Kabupaten Konawe Selatan Tahun 2015. Teknik sampling menggunakan stratified random sampling, yaitu semua wilayah diambil dengan jumlah sampel yang telah diidentifikasi mewakili populasi (Nursalam, 2008).

Ukuran sampel adalah 56 responden, terdiri dari 28 sampel kasus dan 20 sampel kontrol. Semua responden mengisi kuesioner yang berisi pertanyaan tertutup tentang variabel-variabel yang diteliti, meliputi; penggunaan APD, lama pemaparan, dan status gizi pekerja. Penentuan status gizi pekerja berdasarkan pengukuran nilai IMT; pengukuran tinggi badan dengan alat micro toys dan penimbangan berat badan dengan timbangan portable. Hasil pengukuran kemudian dianalisis secara deskriptif dan tabulasi silang.

\section{HASIL PENELITIAN}

Tabel 1. Distribusi Responden Berdasarkan Penggunaan APD

\begin{tabular}{cccc}
\hline \multirow{2}{*}{ APD } & \multicolumn{2}{l}{ Status Bronchitis } & Jumlah \\
\cline { 2 - 3 } & Ya & Tidak & \\
\hline Tidak & 22 & 16 & 38 \\
\hline Ya & 6 & 12 & 18 \\
\hline Jumlah & 28 & 28 & 56 \\
\hline
\end{tabular}

Berdasarkan Tabel 1. menunjukkan $32,1 \%$ responden menggunakan alat pelindung diri dan $67,9 \%$ responden yang tidak menggunakan alat pelindung diri. proporsi responden yang tidak menggunakan alat pelindung diri dan menderita bronchitis sebesar $78,6 \%$ dan proporsi responden yang tidak menggunakan alat pelindung diri dan tidak menderita bronchitis sebesar $57,1 \%$. Proporsi responden yang menggunakan alat pelindung diri dan menderita bronchitis sebesar $21,4 \%$ dan proporsi responden yang menggunakan alat pelindung diri dan tidak menderita bronchitis sebesar $42,9 \%$.

Berdasarkan hasil uji statistik risk estimate diperoleh nilai Odds Ratio (OR) = 2,750 dengan nilai Confidende linterval (CL) 95\% yang memberikan batas bawah (Lower Limit) $=0,851$ dan batas atas $($ Upper Limit $)=$ 8,884. Nilai tersebut menunjukkan bahwa penggunaan alat pelindung diri bukan merupakan faktor yang mempengaruhi kejadian bronchitis pada masyarakat pemecah batu resiko terendah 0,851 dan resiko tertinggi 8,884 dimana masyarakat pemecah batu pada kelompok yang tidak menggunakan alat pelindung diri mempunyai resiko 2,750 kali lebih besar untuk mengalami kejadian bronchitis dibandingkan dengan masyarakat pemecah batu pada kelompok yang menggunakan alat pelindung diri namun tidak konsisten. 
Tabel 2. Distribusi Responden Berdasarkan Paparan

\begin{tabular}{cccc}
\hline \multirow{2}{*}{ Paparan } & \multicolumn{2}{c}{ Status Bronchitis } & \multirow{2}{*}{ Jumlah } \\
\cline { 2 - 3 } & Ya & Tidak & \\
\hline Terpapar & 21 & 11 & 32 \\
\hline Tidak & 7 & 17 & 24 \\
\hline Jumlah & 28 & 28 & 56 \\
\hline
\end{tabular}

Berdasarkan Tabel 2. menunjukkan $57,1 \%$ responden dengan kategori terpapar, dan $42,9 \%$ responden denga kategori tidak terpapar. proporsi responden dengan kategori terpapar dan menderita bronchitis sebesar $75,0 \%$ dan proporsi responden dengan kategori tidak terpapar dan tidak menderita bronchitis sebesar $39,1 \%$. Proporsi responden dengan terpapar dan menderita bronchitis sebesar $25,0 \%$ dan proporsi responden dengan kategori tidak terpapar dan tidak menderita bronchitis sebesar $60,7 \%$.

Berdasarkan hasil uji statistik risk estimate diperoleh nilai Odds Ratio $(\mathrm{OR})=$ 4,636 dengan nilai Confidende linterval (CL) $95 \%$ yang memberikan batas bawah (Lower Limit) $=1,478$ dan batas atas (Upper Limit) $=$ 14,543. Nilai tersebut menunjukkan bahwa lama paparan merupakan faktor yang mempengaruhi kejadian bronchitis pada masyarakat pemecah batu dengan resiko terendah 1,478 dan resiko tertinggi 14,543 dimana masyarakat pemecah batu pada kelompok terpapar dengan masa kerja $\geq 5$ tahun dengan lama kerja $>9$ jam perhari mempunyai resiko 4,636 kali lebih besar untuk mengalami kejadian bronchitis dibandingkan dengan masyarakat pemecah batu pada kelompok yang tidak terpapar dengan masa kerja kurang dari 9 jam perhari.

Tabel 3. Distribusi Responden Berdasarkan Status Gizi

\begin{tabular}{cccc}
\hline \multirow{2}{*}{ Status Gizi } & \multicolumn{2}{l}{ Status Bronchitis } & \multirow{2}{*}{ Jumlah } \\
\cline { 2 - 3 } & Ya & Tidak & \\
\hline Tidak Normal & 13 & 6 & 19 \\
\hline Normal & 15 & 22 & 37 \\
\hline Jumlah & 28 & 28 & 56 \\
\hline
\end{tabular}

Tabel 3. menunjukkan bahwa dari 56 orang responden masyarakat pemecah batu berdasarkan status gizi, distribusi terbesar berada kelompok responden dengan kategori status gizi normal berjumlah 37 orang (66.1\%) yang terdiri dari 15 orang responden yang menderita bronchitis dan 22 orang responden yang tidak menderita bronchitis.

Berdasarkan hasil uji statistik risk estimate diperoleh nilai Odds Ratio $(\mathrm{OR})=$ 3,178 dengan nilai Confidende linterval (CL) 95\% yang memberikan batas bawah (Lower Limit $)=0,987$ dan batas atas (Upper Limit) $=$ 10,228 . Nilai tersebut menunjukkan bahwa status gizi bukan merupakan faktor yang mempengaruhi kejadian bronchitis pada masyarakat pemecah batu, dengan resiko terendah 0,987 dan resiko tertinggi 10,228. Masyarakat pemecah batu pada kelompok responden status gizi tidak normal mempunyai resiko 3,178 kali lebih besar untuk mengalami kejadian bronchitis dibandingkan dengan kelompok responden dengan status gizi tidak normal.

\section{PEMBAHASAN \\ Penggunaan APD (Alat Pelindung Diri )}

Penggunaan APD secara sederhana adalah seperangkat alat yang digunakan tenaga kerja untuk melindungi sebagian atau seluruh tubuhnya dari adanya potensi bahaya atau kecelakaan kerja. APD tidaklah secara sempurna melindungi tubuh, akan tetapi dapat mengurangi tingkat keparahan yang mungkin dapat terjadi. Pekerja yang aktivitas pekerjaannya banyak terpapar oleh partikel debu memerlukan alat pelindung diri berupa masker untuk mereduksi jumlah partikel yang kemungkinan dapat terhirup. Pekerja yang taat menggunakan masker pada saat bekerja pada area yang berdebu akan meminimalkan jumlah paparan partikel debu yang dapat terhirup. Selain jumlah paparan, ukuran partikel yang kemungkinan lolos dari masker menjadi kecil (Budiono, 2007).

Tidak signifikannya penggunaan APD terhadap kejadian bronchitis dapat terjadi karena APD yang digunakan oleh pekerja tidak sesuai dengan ketentuan atau standar APD. Selain itu kebiasaan pekerja yang hanya menggunakan APD jika pada situasi atau kondisi yang sudah sangat mengganggu kenyamanan para pekerja. Perbedaan ini pula 
terlihat pada kualitas bahan baku batu yang dapat menjadi sebab perbedaan paparan antara para pekerja dimana para pekerja yang jauh dari sumber bahan baku lebih memilih membeli bahan baku dari para pemecah batu tebing dengan kondisi paparan debu yang relatif lebih sedikit dibandingkan dengan pekerja yang mangambil bahan baku langsung dengan kondisi lingkungan dan resiko paparan debu lebih banyak.

\section{Lama Pemaparan}

Lama paparan adalah lamanya seorang tenaga kerja (tahun) terpapar dengan lingkungan kerja, dihitung mulai saat bekerja sampai penelitian berlangsung. Semakin lama seseorang dalam bekerja maka semakin banyak terpapar bahaya yang ditimbulkan oleh lingkungan kerja tersebut. Morgan dan Parkes dalam Budiono (2007) menyatakan waktu yang dibutuhkan seseorang terpapar oleh debu untuk terjadinya gangguan fungsi paru yaitu lebih dari 10 tahun. Kemudian, penelitian Sumanto (1999) dalam Budiono (2007) menunjukan bahwa semakin lama seseorang bekerja pada lingkungan berdebu, maka dapat menurunkan kapasitas vital paru. Setiap penambahan masa kerja dalam satu tahun akan terjadi penurunan kapasitas paru sebesar $35,39 \mathrm{ml}$.

Variabel lama paparan bukan merupakan faktor risiko yang secara langsung berhubungan dengan gangguan pernapasan. Keadaan ini disebabkan karena variabel lama paparan tidak dapat berdiri sendiri untuk mempengaruhi gangguan pernapasan, sehingga memerlukan variabel lain untuk bersama-sama mempengaruhi gangguan pernapasan.

\section{Status Gizi Pekerja}

Kelompok responden dengan status gizi tidak normal sebanyak 19 orang (33.9\%) yang terdiri dari 13 orang responden yang menderita bronchitis dan 6 orang responden yang tidak menderita bronchitis. Sejalan dengan penelitian Yuliani (2010) yaitu berdasarkan hasil uji statistik, hubungan antara status gizi dengan kapasitas vital paru pada pekerja tenun didapatkan tidak ada hubungan signifikan antara status gizi dengan kapasitas vital paru. Selanjutnya sejalan juga dengan penelitian Khumaidah (2009) pada pekerja furniture, hasil penelitian menunjukan tidak ada hubungan antara status gizi pekerja dengan gangguan fungsi paru.

Indeks Massa Tubuh (IMT) merupakan salah satu indikator untuk menilai status gizi seseorang. Status gizi buruk akan menyebabkan daya tahan tubuh seseorang akan menurun, sehingga dengan menurunnya daya tahan tubuh, seseorang akan mudah terinfeksi oleh mikroba. Berkaitan dengan infeksi saluran napas, apabila terjadi secara berulang-ulang dan disertai batuk berdahak, akan dapat menyebakan terjadinya bronchitis kronis. Salah satu akibat kekurangan gizi dapat menurunkan imunitas dan antibody sehingga seseorang mudah terserang penyakit infeksi seperti batuk, pilek dan berkurangnya kemampuan tubuh untuk melakukan detoksifikasi terhadap benda asing seperti debu yang masuk ke dalam tubuh (Khumaidah, 2009).

\section{KESIMPULAN}

Berdasarkan hasil analisis faktor penggunaan APD, lama pemaparan, dan Status Gizi pekerja terhadap kejadian Bronchitis pada pekerja pemecah baru di wilayah kerja Puskesmas Lalowaru Kecamatan Moramo Utara Kabupaten Konawe SelataN, maka dapat di tarik kesimpulan bahwa lama pemaparan mempunyai pengaruh yang signifikan terhadap kejadian bronchitis pada masyarakat pekerja pemecah batu di wilayah kerja Puskesmas Lalowaru Kecamatan Moramo Utara Kabupaten Konawe Selatan tahun 2015, selain itu Penggunaan APD dan Status Gizi pekerja tidak memiliki pengaruh yang signifikan terhadap kejadian bronchitis pada masyarakat pekerja pemecah batu di wilayah kerja Puskesmas Lalowaru Kecamatan Moramo Utara Kabupaten Konawe Selatan.

Berdasarkan penelitian yang dilakukan pada pekerja pemecah batu tersebut mengenai kejadian bronchitis akibat lama pemaparan, maka perlu diupayakan agar para pekerja pemecah batu senantiasa melakukan pemeriksaan secara periodik dan teratur 
untuk memantau kondisi kesehatan fisik tanpa harus menunggu timbulnya suatu penyakit khususnya penyakit paru yang jika terlambat dapat berakibat fatal.

\section{DAFTAR PUSTAKA}

Budiono, I., (2007). Faktor risiko gangguan fungsi paru pada pekerja pengecatan mobil. Tesis. Pascasarjana Universitas Diponegoro Semarang.

Khumaidah, (2009). Analisis faktor-faktor yang berhubungan dengan gangguan fungsi paru pada Pekerja Mebel PT. Kota Jati Furnindo Desa Suwawal Kecamatan Mionggo Kabupaten Jepara Tesis.
Program Pasca Sarjana Universitas Diponegoro. Semarang. http://eprints. undip.ac.id. di akses tanggal 16 November 2015

Lestari, K., (2000). Pengaruh Paparan Debu terhadap Fungsi Ventilasi Paru Tenaga Kerja Plywood. Majalah Hiperkes dan Keselamatan Kerja. No.33:2.

Noor, N.N., (2008). Pengantar Epidemiologi Edisi Revisi, Rineka Cipta. Jakarta.

Nursalam, 2008. Metodologi Penelitian Kesehatan. PT. Erlangga, Jakarta.

Yuliani, S. dkk., (2010). Analisis potensi bahaya dan upaya pengendalian risiko bahaya pada Pekerja Pemecah Batu. FKM Universitas Diponegoro. Semarang. 